\title{
Biochemical Production of Ethanol from Corn Stover: 2007 State of Technology Model
}

Technical Report NREL/TP-510-43205 May 2008

Andy Aden

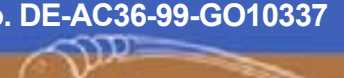




\section{Biochemical Production of}

Ethanol from Corn Stover: 2007 State of Technology Model

Technical Report NREL/TP-510-43205 May 2008

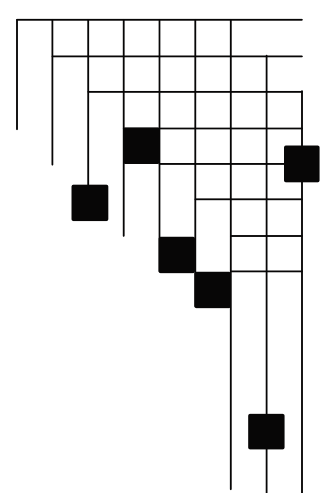

\section{Andy Aden}

Prepared under Task No. BB07.2410 


\section{NOTICE}

This report was prepared as an account of work sponsored by an agency of the United States government. Neither the United States government nor any agency thereof, nor any of their employees, makes any warranty, express or implied, or assumes any legal liability or responsibility for the accuracy, completeness, or usefulness of any information, apparatus, product, or process disclosed, or represents that its use would not infringe privately owned rights. Reference herein to any specific commercial product, process, or service by trade name, trademark, manufacturer, or otherwise does not necessarily constitute or imply its endorsement, recommendation, or favoring by the United States government or any agency thereof. The views and opinions of authors expressed herein do not necessarily state or reflect those of the United States government or any agency thereof.

Available electronically at http://www.osti.gov/bridge

Available for a processing fee to U.S. Department of Energy and its contractors, in paper, from:

U.S. Department of Energy

Office of Scientific and Technical Information

P.O. Box 62

Oak Ridge, TN 37831-0062

phone: 865.576 .8401

fax: 865.576 .5728

email: mailto:reports@adonis.osti.gov

Available for sale to the public, in paper, from:

U.S. Department of Commerce

National Technical Information Service

5285 Port Royal Road

Springfield, VA 22161

phone: 800.553.6847

fax: 703.605.6900

email: orders@ntis.fedworld.gov

online ordering: http://www.ntis.gov/ordering.htm 


\section{Contents}

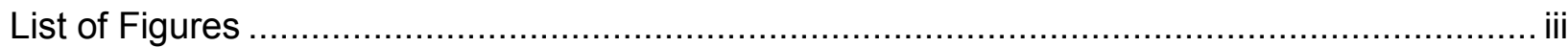

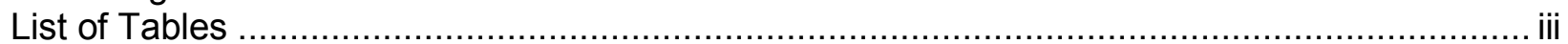

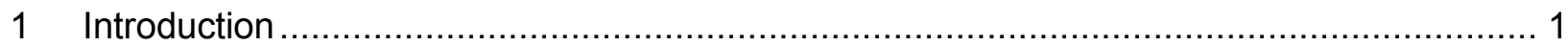

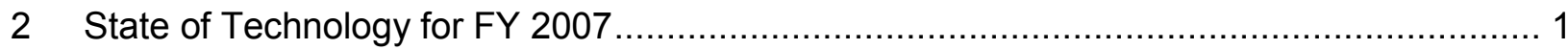

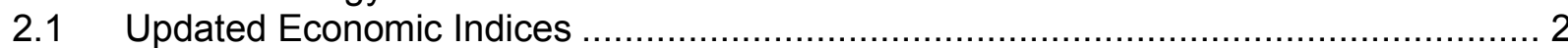

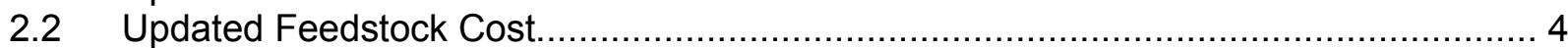

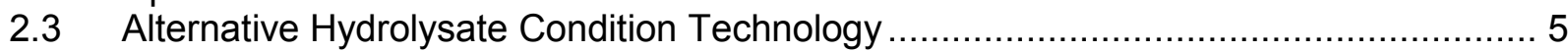

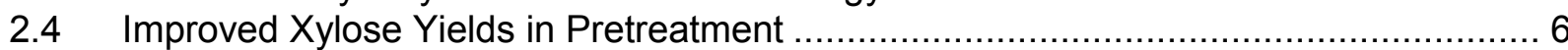

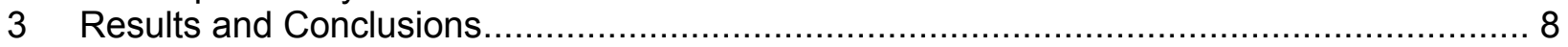

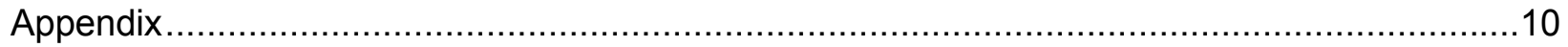

\section{List of Figures}

Figure 1. State of technology progress toward the 2012 goal (in 2002 dollars) ........................ 2

Figure 2. Chemical engineering plant cost index, July 2007 (see www.che.com) ................... 3

Figure 3. Progression from $\$ 1.07 /$ gal cost target to $\$ 1.33 /$ gal cost target .............................. 4

Figure 4. Xylan component closure and yields for corn stover pretreatment in ZipperClave and

steam gun reactors ...................................................................................................... 7

Figure 5. State of technology progress toward the 2012 goal (estimated 2007 dollars) ............. 9

\section{List of Tables}

Table 1. Conditioning Data Used in State of Technology Models ......................................... 6

Table 2. Pretreatment Data and Processing Conditions Used in State of Technology Models ... 8

Table 3. State of Technology Summary .................................................................. 9 


\section{Introduction}

In 2002, the National Renewable Energy Laboratory (NREL) published a detailed report ${ }^{1}$ documenting a process design and economic analysis for the biochemical conversion of lignocellulosic biomass (corn stover) to ethanol. The design makes use of dilute acid pretreatment followed by enzymatic saccharification and cofermentation with recombinant Zymomonas mobilis. This design is not optimized; rather, it represents one technology package. Although experimentally verified data are contained in the report, it serves a more important function - to set the technological targets necessary for attaining U.S. Department of Energy (DOE) cost goals. This report still serves as the basis for the 2012 DOE goals.

The material and energy balances contained in the report were generated using Aspen Plus models created by NREL. The data were then placed in a spreadsheet framework for economic calculations. Using a discounted cash flow rate of return analysis, we calculated the minimum ethanol selling price (MESP) needed to meet a 10\% internal rate of return for a biorefinery capable of producing 2,000 dry metric tonnes per day. An " $\mathrm{N}^{\text {th" }}$ plant assumption was used to eliminate any first-of-a-kind costs that might be incurred while building the pioneer facilities. In year-2000 dollars, this equated to $\$ 1.07$ per gallon $(\$ 1.07 / \mathrm{gal})$ ethanol. When inflation is factored into capital, chemicals, and labor costs, this MESP equates to $\$ 1.33 /$ gal ethanol, in estimated 2007 dollars.

\section{State of Technology for FY 2007}

Since 2001, NREL has kept track of technical research progress in the biochemical process through what are known as "State of Technology" (SOT) assessments. Once termed "experimentally verified" cases, these annual updates are an essential activity at NREL. Data generated at either the bench or pilot scale in the research and development (R\&D) areas of pretreatment, conditioning, enzymatic hydrolysis, and fermentation are input to technoeconomic models in order to calculate what the commercial-scale economics might be under specific conditions. This allows researchers to quantify progress achieved in the laboratory in terms of economic improvements in the overall cellulosic ethanol process. As such, progress toward the 2012 goal of cost-competitive ethanol can easily be seen. Researchers are also able to determine where process improvements are needed and where research efforts and funds should be focused.

The purpose of this report is to update the FY 2005 SOT model with the latest research results from the past two years. Because of budget limitations and resource constraints, an FY 2006 assessment was never completed. A technical memo describing the FY 2005 state of technology results (Doc. \#9382) ${ }^{2}$ is not yet available to the public. The MESP resulting from that assessment was $\$ 2.26 /$ gal, in year-2002 dollars. In addition, all prior assessments were described in the same 2002 dollars, as was the design case cost target of $\$ 1.07 /$ gal. These are shown in Figure 1.

\footnotetext{
${ }^{1}$ A. Aden et al., Lignocellulosic Biomass to Ethanol Process Design and Economics Utilizing Co-Current Dilute Acid Prehydrolysis and Enzymatic Hydrolysis for Corn Stover, NREL/TP-510-32438, Golden, CO, June 2002. www.nrel.gov/docs/fy02osti/32438.pdf

$\frac{2}{2}$ J. Jechura, "Sugar Platform Post-Enzyme Subcontract Case," NREL Technical Memorandum, Doc. \#9382, October 11, 2005.
} 


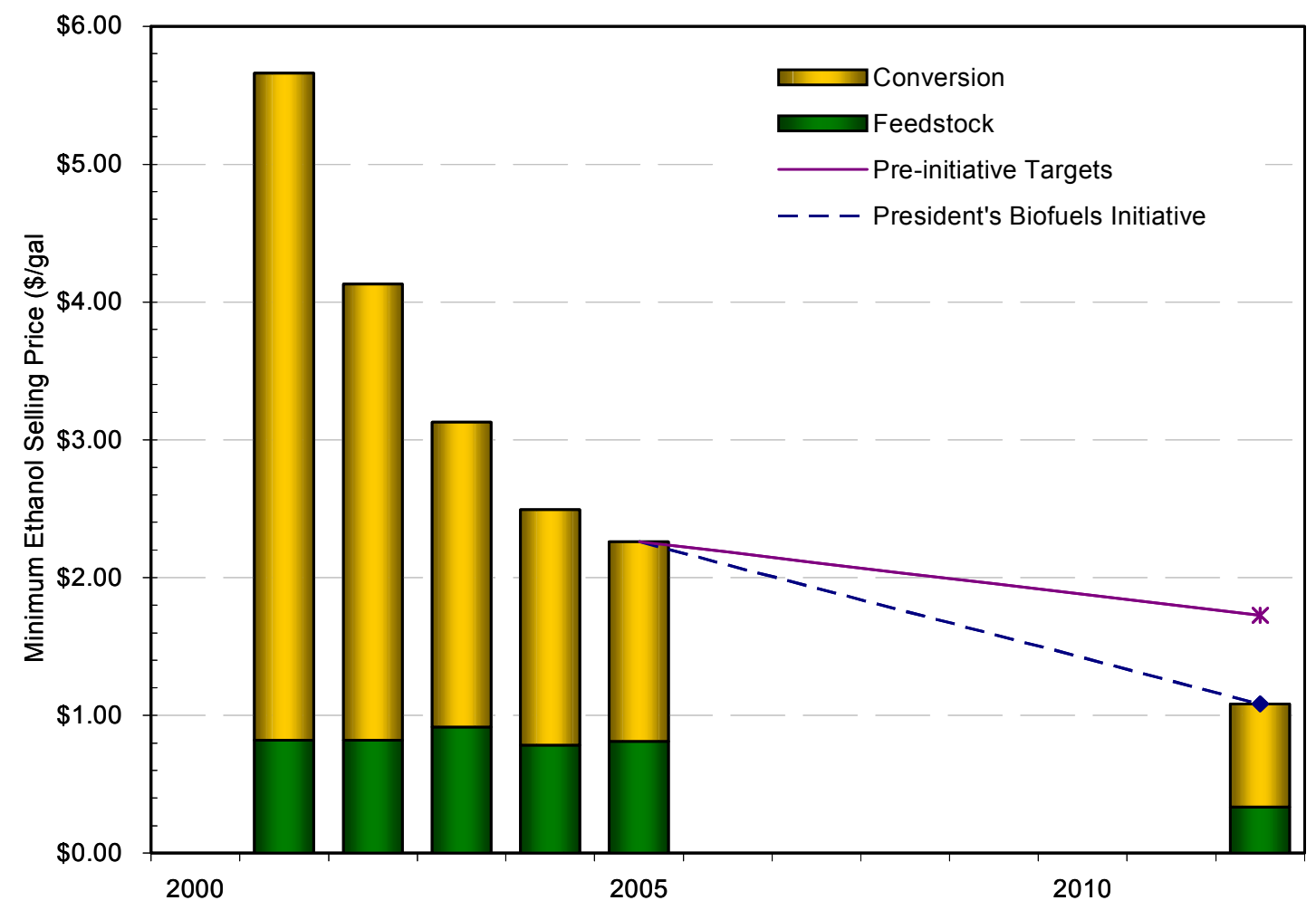

Figure 1. State of technology progress toward the 2012 goal (in 2002 dollars)

Four changes were made to update the FY 2005 SOT model to an FY 2007 SOT model:

1. Updated economic indices from 2002 dollars to estimated 2007 dollars

2. Updated feedstock cost

3. Investigated alternative hydrolysate conditioning (ammonium hydroxide)

4. Improved monomeric xylose yields from xylan during pretreatment

\subsection{Updated Economic Indices}

Several cost indices are used within the model to update capital, raw material, and labor costs to the desired costing year. These cost indices have risen dramatically since 2002 as a result of a variety of international pressures affecting the availability of steel and skilled labor. As an example, the chemical plant cost indices, which are used to index capital costs in the model, are shown in Figure 2.

In addition, a newly developed feedstock cost index was used to index the delivered corn stover cost to the proper year-dollars. The index was developed by researchers at Idaho National Laboratory (INL). This specifically impacted the 2012 design case by increasing the feedstock 
cost from $\$ 35 /$ dry ton in 2002 dollars to $\$ 46 /$ dry ton in estimated 2007 dollars. The impact of this feedstock cost increase is shown in Figure 3, along with other updated indices.

As a result, the process economics and cost targets rise significantly when updated to estimated year-2007 dollars. The 2012 cost target rose from $\$ 1.07 /$ gal in 2002 dollars to $\$ 1.33 /$ gal in estimated 2007 dollars (see the progression in Figure 3). Actual indices were reported only through 2006; actual 2007 indices will be available some time in 2008. These cost numbers are estimated from the first few months' index values.

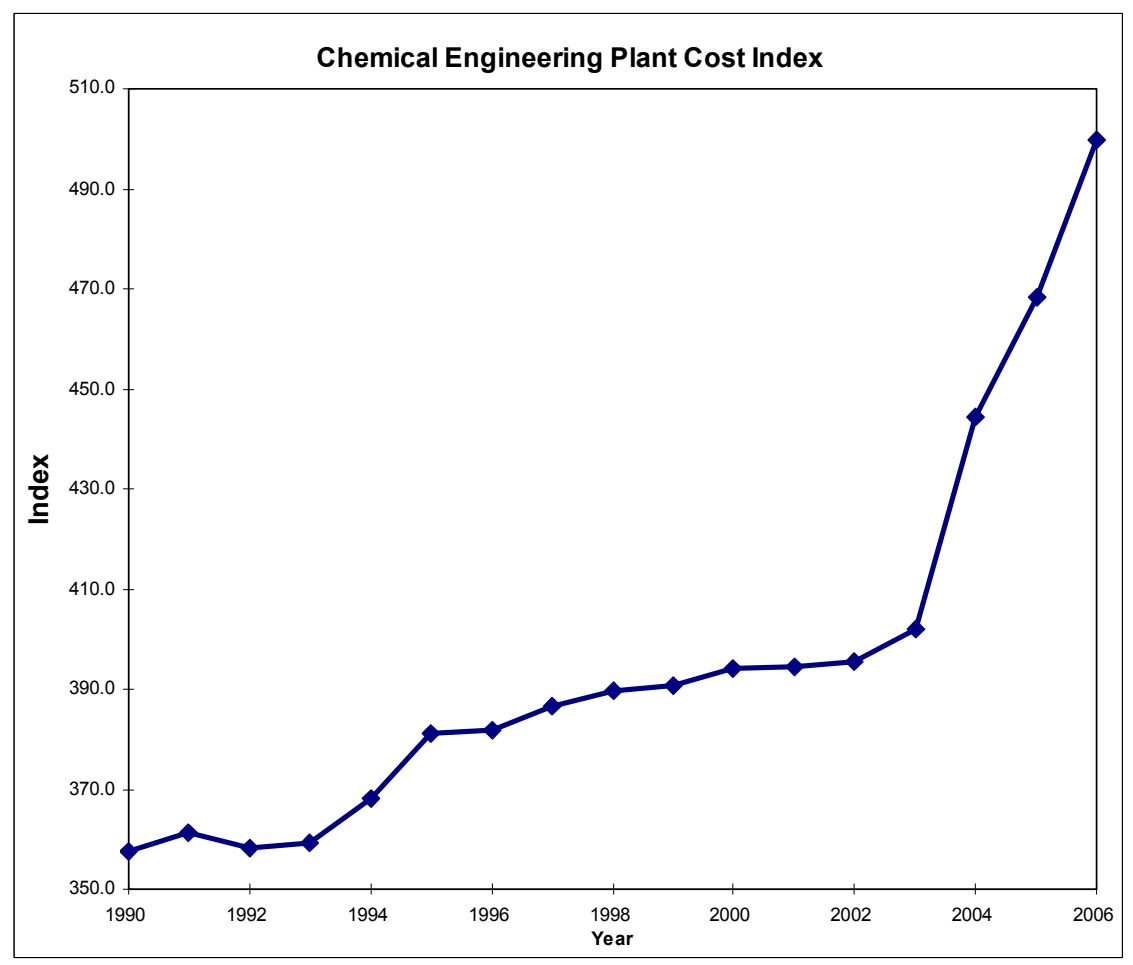

Figure 2. Chemical engineering plant cost index, July 2007 (see www.che.com) 


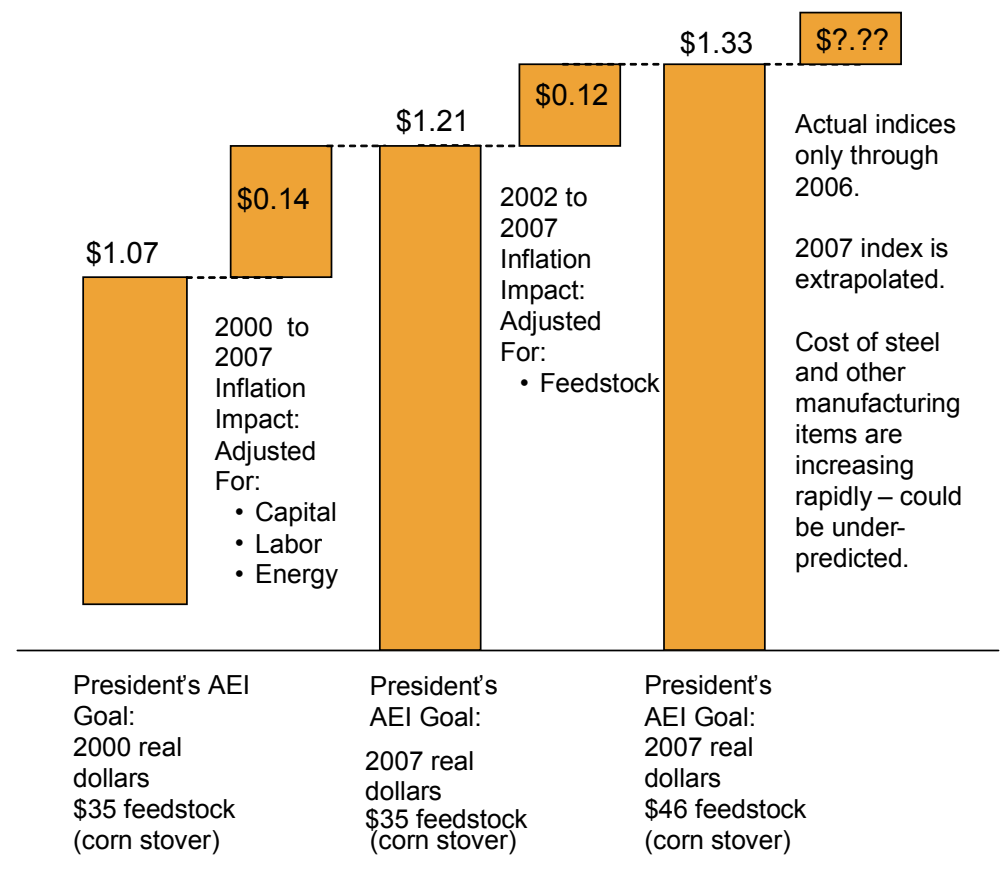

Figure 3. Progression from $\$ 1.07 /$ gal cost target to $\$ 1.33 /$ gal cost target

\subsection{Updated Feedstock Cost}

The feedstock cost used in the FY 2005 SOT model was $\$ 53 /$ dry ton delivered to the plant gate. Since then. researchers at INL have made further developments to the feed-handling logistics needed to bring the stover from the field to the biorefinery. The feed-handling logistics designs and targets are described in more detail in the DOE Biomass Program's Multi-Year Program Plan (MYPP) ${ }^{3}$. The important distinction now is that the new 2007 feedstock cost represents a cost of feedstock delivered (in the proper form and quality) to the throat of the pretreatment reactor. Therefore, any on-site feed handling (bale breaking, washing, etc.) is now included as part of the overall delivered cost of $\$ 60 /$ dry ton.

A large amount of research has been conducted and reported on under the biochemical platform since the last SOT case was developed in FY 2005. This includes research conducted on biomass characterization and sample analysis, new surface characterization imaging techniques and results, and pretreatment and enzymatic conversion experiments at both the bench and pilot scales. Some experimental data (e.g., testing of advanced enzyme preparations by Genencor or Novozymes) remains protected by a Cooperative Research and Development Agreement, or CRADA, and therefore cannot be used as part of this assessment. "Knowledge" enhancements include improved sample analysis methods or updated knowledge of the relationship between enzyme structure and function on cellulosic substrate. These help to enhance the quality of research being done at NREL, but at present are difficult to capture as specific and applied process improvements within the model. They will undoubtedly lead to cost reductions in later

\footnotetext{
${ }^{3}$ U.S. Department of Energy, Biomass Multi-Year Program Plan, November 2007, Biomass Program, Office of Energy Efficiency and Renewable Energy, Washington, D.C.
} 
years as the knowledge is applied. Process improvements that are being captured as part of the FY 2007 SOT are alternative conditioning and improved xylose yield.

\subsection{Alternative Hydrolysate Condition Technology}

The 2005 state of technology documented significant sugar degradation (13\% xylose, 12\% glucose) as a result of using a process known as "overliming" to condition the dilute acid hydrolysate. Consequently, alternative conditioning technologies were investigated by researchers. A milestone report prepared by Jennings et al. ${ }^{4}$ in December 2006 evaluated the effectiveness of lime and ammonium hydroxide as conditioning agents for dilute acid pretreated corn stover. Pretreated stover was produced in a pilot-scale reactor, and liquor extracted from the pretreated slurry was treated with an "overliming" process or with ammonium hydroxide at various concentrations and treatment temperatures. Glucose (spiked) and xylose were fermented to ethanol using recombinant Zymomonas mobilis $8 \mathrm{~b}$. A shake flask screening study identified conditions in which the treatment with ammonium hydroxide did not result in the sugar losses normally seen during overliming treatments. Improved fermentation yields were also observed when researchers used ammonium hydroxide rather than overliming.

Using these data, researchers conducted an economic evaluation ${ }^{5}$ to determine the potential economic impact of alternative conditioning agents on the overall process. At the base-case conditions chosen, the use of ammonium hydroxide appeared to have minimal economic benefit. In general, the benefits of lower sugar losses (increasing the sugar available for fermentation) were counterbalanced by the increased cost of the detoxification agent (ammonia vs. lime). In the end, a slight improvement in MESP was found to result from the improved fermentation yields.

This model showed that the economics were strongly dependent on both the fermentation yields and the price of ammonia. Although laboratory experiments did show a fermentation yield increase as a result of using ammonium hydroxide, this was not captured as part of the FY 2007 SOT assessment because relatively high ethanol yields ( $85 \%$ glucose conversion, $76 \%$ xylose conversion) were already modeled in the FY 2005 SOT. As new integrated testing data become available, fermentation yield improvements may in fact be seen.

Using ammonium hydroxide during conditioning may also negate the need for solid-liquid separations of the hydrolysate slurry before conditioning. When lime is used as a conditioning agent, it is applied to the hydrolysate liquor fraction only. An insoluble agent such as this does not disperse well in a high-solids slurry. However, ammonium hydroxide is a liquid, which has a much easier time dispersing throughout the entire hydrolysate slurry. As a result, costly solidliquids separation equipment could potentially be eliminated from the overall design. A more detailed look at this issue, and the potential ramifications downstream, will be done before this design change is included in a state of technology assessment. Water recycle effects and the destination of ammoniated compounds are two specific items to be investigated.

\footnotetext{
${ }^{4}$ E. Jennings and D. Schell, "Evaluate Alternative Conditioning Technology With the Potential to Eliminate Sugar Losses,” NREL Milestone completion report, Dec. 30, 2006, Doc. \#9777.

${ }^{5}$ A. Aden, "Economic Evaluation of Alternative Conditioning Technology," NREL Technical Memo, April 5, 2007, Doc. \#9865.
} 
Sugar losses during conditioning with ammonium hydroxide were significantly lower $(0.6 \%$ glucose, $1.8 \%$ xylose) than they were with overliming. This brought the state of technology much closer to the goals represented in the 2012 case for conditioning (1\% xylose loss, $0 \%$ glucose loss). The conditioning data input to the model are shown in Table 1 and compared with the data used in the FY 2005 SOT.

Table 1. Conditioning Data Used in State of Technology Models

\begin{tabular}{|l|c|c|}
\hline Conditions & FY 2005 SOT & FY 2007 SOT \\
\hline Temperature $\left({ }^{\circ} \mathrm{C}\right)$ & 50 & 30 \\
\hline Conditioning agent & Lime & Ammonium Hydroxide \\
\hline Conversions & & \\
\hline Glucose sugar loss & $12.0 \%$ & $0.6 \%$ \\
\hline Xylose sugar loss & $13.0 \%$ & $1.8 \%$ \\
\hline Arabinose sugar loss & $20.0 \%$ & $1.8 \%$ \\
\hline Mannose sugar loss & $0 \%$ & $0.6 \%$ \\
\hline Galactose sugar loss & $28.0 \%$ & $0.6 \%$ \\
\hline
\end{tabular}

\subsection{Improved Xylose Yields in Pretreatment}

The 2005 state of technology documented a xylan-to-monomeric xylose conversion of $63 \%$ using dilute acid pretreatment. In 2007, a milestone report by Weiss et al. ${ }^{6}$ documented the progress thus far in improving xylan-to-xylose conversion in the dilute acid pretreatment process. Two bench-scale pretreatment reactor systems were operated at high-solids loadings for $1 / 4$-inch and $3 / 4$-inch particles of whole corn stover. The particles were impregnated with $1.1 \%$ $(\mathrm{wt} / \mathrm{wt}$ ) sulfuric acid and pretreated in both the ZipperClave (2-liter) and steam gun (4-liter) reactors at temperatures ranging from $180^{\circ}$ to $200^{\circ} \mathrm{C}$ and reaction times between 1 and 2 minutes. Results from the liquor and solids analysis indicated that the yield target of $75 \%$ conversion to xylose was exceeded in several instances. These results, shown in Figure 4, were achieved in both reactors for both particle sizes. As expected, higher levels of degradation products (furfural) were obtained at the high-severity conditions. Depending on the reactor system and conditions, approximately $3 \%-10 \%$ of the xylan was recovered as oligomeric xylose. Building on this work, the 2008 target for the platform is to demonstrate this same $75 \%$ target at a larger continuous scale.

\footnotetext{
${ }^{6}$ N. Weiss et al., "Achieve 75\% Xylose Yield in Laboratory Scale High Solids Pretreatment Reactor," NREL Milestone Completion Report, June 30, 2007, Doc. \#9926.
} 


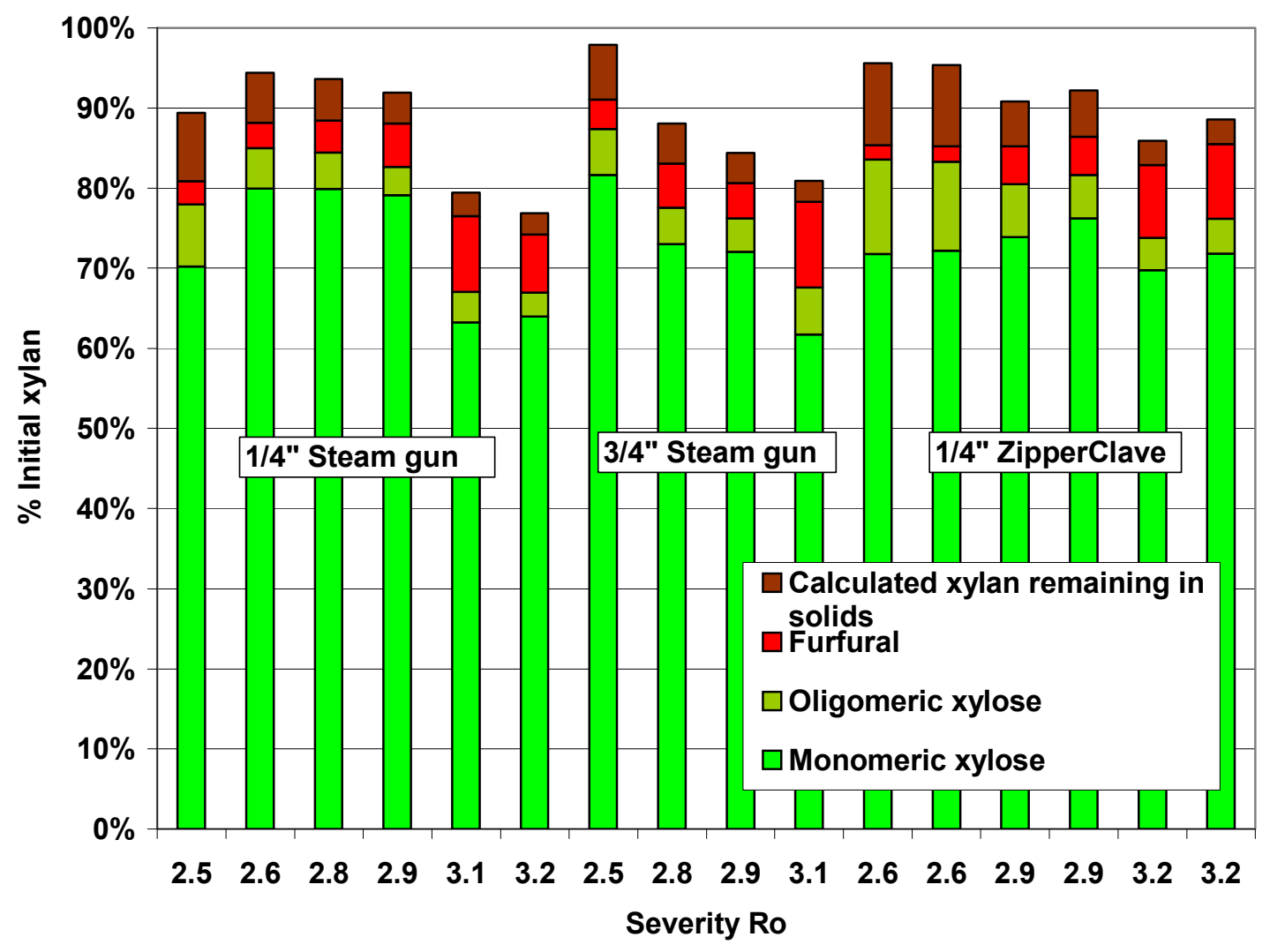

Figure 4. Xylan component closure and yields for corn stover pretreatment in ZipperClave and steam gun reactors

The focus of this work was on xylan conversion; however, some cellulose hydrolysis, with resulting glucose formation, did occur as well. Total glucose yields generally ranged between $10 \%$ and $20 \%$, with very little degradation to hydroxymethylfurfural (HMF).

The pretreatment data were used in the FY 2007 SOT process model. Specifically, an average of the results was used from the ZipperClave at severity (Ro) of 2.9 using a $1 / 4$-inch stover particle size. The reactor temperature was $190^{\circ} \mathrm{C}$, residence time was 105 seconds, reactor acid concentration was $1.64 \%(\mathrm{wt} / \mathrm{wt})$, and total solids loading was $46 \%$. The data input to the model are shown in Table 2 in comparison to the data used in the FY 2005 SOT. In the model, the solids loading to the reactor remained at $30 \%$ total solids. Xylan conversion to "tar" is used in the model to capture differences between the initial and final insoluble components not identified as "xylan." In this fashion, the 5.7\% remaining xylan shown in Figure 5 is equivalent to 5.7\% unconverted xylan in the model. Because other hemicellulosic sugars (arabinose, galactose, mannose) were not measured during pretreatment but behave similarly, they were given identical conversions to xylan. 
Table 2. Pretreatment Data and Processing Conditions Used in State of Technology Models

\begin{tabular}{|l|c|c|}
\hline Conditions & FY 2005 SOT & FY 2007 SOT \\
\hline Temperature $\left({ }^{\circ} \mathrm{C}\right)$ & 190 & 190 \\
\hline Acid concentration $(w t \%)$ & $1.90 \%$ & $1.64 \%$ \\
\hline Solids loading $(w \mathrm{wt} \%)$ & $30 \%$ & $30 \%$ \\
\hline Conversions & & \\
\hline Cellulose $\rightarrow$ glucose olig & $2.7 \%$ & $0.3 \%$ \\
\hline Cellulose $\rightarrow$ glucose & $18.5 \%$ & $9.9 \%$ \\
\hline Cellulose $\rightarrow$ HMF & $0.0 \%$ & $0.3 \%$ \\
\hline Xylan $\rightarrow$ xylose olig & $10.2 \%$ & $6.0 \%$ \\
\hline Xylan $\rightarrow$ xylose & $63.2 \%$ & $75.0 \%$ \\
\hline Xylan $\rightarrow$ furfural & $10.4 \%$ & $4.8 \%$ \\
\hline Xylan $\rightarrow$ "tar" & $2.4 \%$ & $8.5 \%$ \\
\hline Other hemis to oligs & $10.2 \%$ & $6.0 \%$ \\
\hline Other hemis to monomers & $63.2 \%$ & $75.0 \%$ \\
\hline Other hemis to degrad. prod. & $10.4 \%$ & $4.8 \%$ \\
\hline
\end{tabular}

\section{Results and Conclusions}

As a result of these model changes, the minimum ethanol selling price decreased from $\$ 2.52 /$ gal to $\$ 2.43 /$ gal. The new SOT cost progression curve with the updated FY 2007 SOT case is shown in Figure 5. The economic summary sheet for the FY 2007 SOT case is shown in the appendix. All of the FY 2007 research targets were met and are shown in Table 3. Several basic scientific milestones were achieved that will provide a basis for other out-year cost-reduction milestones.

In FY 2008, significant progress will be made toward the $\$ 1.33 /$ gal target. In particular, benchscale pretreatment results will be validated at larger continuous scale. The relationship between corn stover hydrolysate conditioning and fermentation will be better defined and understood. Commercial cellulase preparations will be analyzed for baseline performance (specific activity), and cellulase function will be better understood. Integrated testing of whole slurry and recycle options will be conducted. Last, the efficacy of advanced enzyme preparations (including oligomerases and/or hemicellulases) will be tested in conjunction with alternative pretreatment technologies. The goal is to reduce the cost of pretreatment, reduce the hydrolysis time, and increase the sugar (xylose and glucose) yields. 


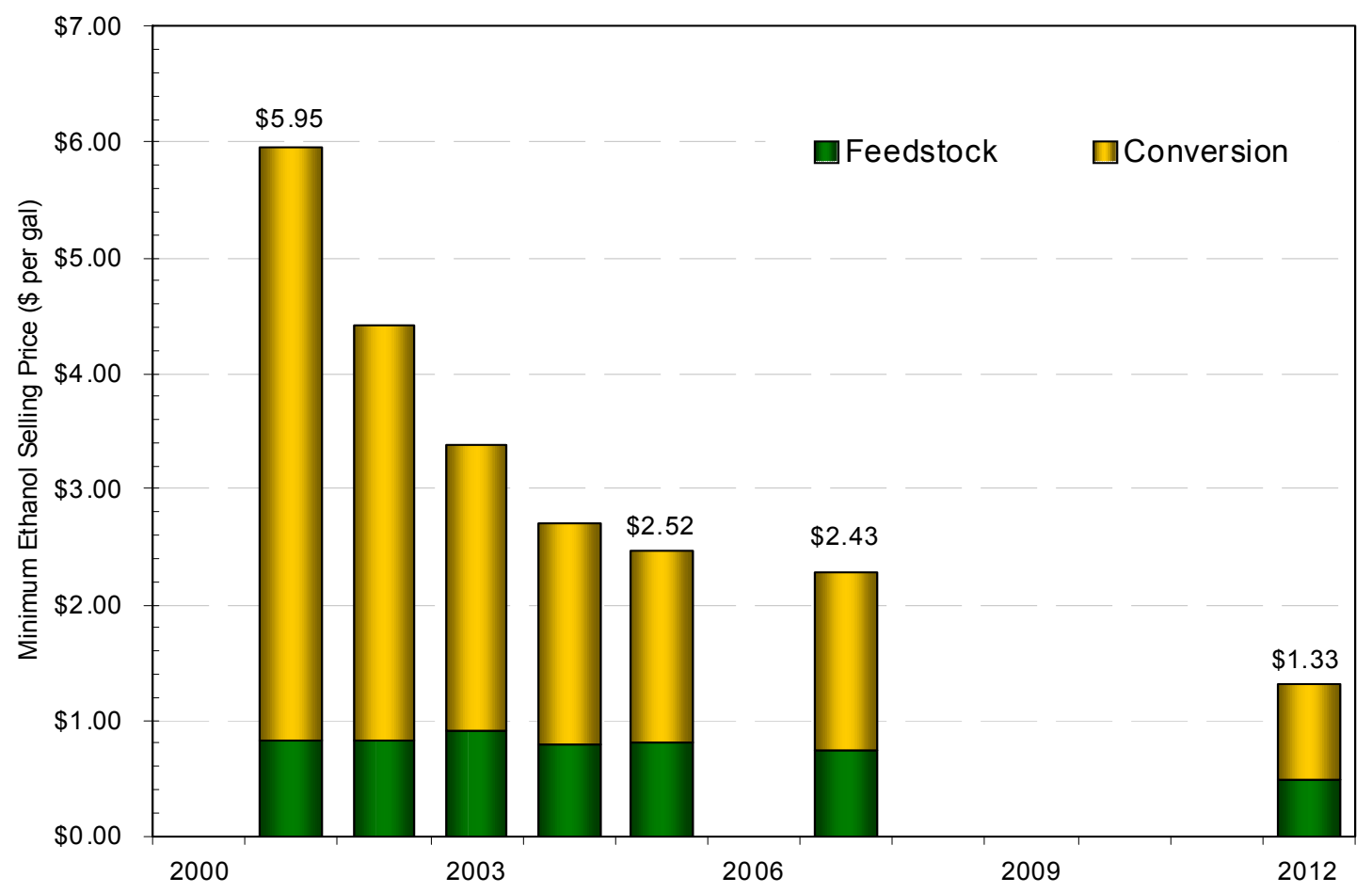

Figure 5. State of technology progress toward the 2012 goal (estimated 2007 dollars)

Table 3. State of Technology Summary

\begin{tabular}{|c|c|c|c|c|c|}
\hline & $\begin{array}{c}2007 \\
\text { Targets }\end{array}$ & $\begin{array}{c}2007 \\
\text { Results }\end{array}$ & 2008 & 2010 & $\begin{array}{c}2012 \\
\text { Market } \\
\text { Target }\end{array}$ \\
\hline Minimum Ethanol Selling Price & & $\$ 2.43$ & & & $\$ 1.33$ \\
\hline TPI/Annual Gallon & & $\$ 4.17$ & & & $\$ 3.17$ \\
\hline Yield (Gallon/dry ton) & 68 & 72 & & & 90 \\
\hline \multicolumn{6}{|l|}{ Feedstock } \\
\hline Feedstock Cost ( $\$ /$ dry ton) & & $\$ 60$ & $\$ 60$ & & $\$ 46$ \\
\hline \multicolumn{6}{|l|}{ Pretreatment } \\
\hline Solids Loading (wt\%) & $30 \%$ & $30 \%$ & $30 \%$ & $30 \%$ & $30 \%$ \\
\hline Xylan to Xylose & $75 \%$ & $75 \%$ & $75 \%$ & $85 \%$ & $90 \%$ \\
\hline Xylan to Degradation Products & $13 \%$ & $13 \%$ & $8 \%$ & $6 \%$ & $5 \%$ \\
\hline \multicolumn{6}{|l|}{ Conditioning } \\
\hline Xylose Sugar Loss & $11 \%$ & $2 \%$ & $2 \%$ & $2 \%$ & $1 \%$ \\
\hline Glucose Sugar Loss & $12 \%$ & $1 \%$ & $1 \%$ & $1 \%$ & $0 \%$ \\
\hline \multicolumn{6}{|l|}{ Enzymes } \\
\hline Enzyme Contribution (\$/gal EtOH) & $\$ 0.32$ & $\$ 0.32$ & $\$ 0.32$ & $\$ 0.16$ & $\$ 0.10$ \\
\hline \multicolumn{6}{|l|}{ Saccharification \& Fermentation } \\
\hline Total Solids Loading (wt\%) & $20 \%$ & $20 \%$ & $20 \%$ & $20 \%$ & $20 \%$ \\
\hline Combined Saccharification \& Fermentation Time (d) & 7 & 7 & 7 & 5 & 3 \\
\hline Overall Cellulose to Ethanol & $85 \%$ & $85 \%$ & $85 \%$ & $85 \%$ & $85 \%$ \\
\hline Xylose to Ethanol & $76 \%$ & $76 \%$ & $80 \%$ & $80 \%$ & $85 \%$ \\
\hline Minor Sugars to Ethanol & $0 \%$ & $0 \%$ & $40 \%$ & $80 \%$ & $85 \%$ \\
\hline
\end{tabular}




\section{Appendix}

\section{FY 2007 Biochemical SOT Economic Summary Reference Model: A0802A}

\section{Ethanol Production Process Engineering Analysis}

Corn Stover Design Case: 2007 State of Technology Case

All Values in $2007 \$$

All Values in $2007 \$$

Minimum Ethanol Selling Price \$2.43

\begin{tabular}{|c|c|c|c|}
\hline $\begin{array}{r}\text { Ethan } \\
\text { Ethanol Yield } \\
\text { Int } \\
\text { Eq }\end{array}$ & $\begin{array}{l}\text { roduction (MM G } \\
\text { al / Dry US Ton F } \\
\text { edstock Cost \$/D } \\
\text { I Rate of Return } \\
\text { Percent of Total }\end{array}$ & $\begin{array}{l}55.5 \\
71.9 \\
\$ 60 \\
10 \% \\
100 \%\end{array}$ & \\
\hline Capital Costs & & Operating Costs (cents & nol) \\
\hline Feed Handling & $\$ 0$ & Feedstock & 83.6 \\
\hline Pretreatment & $\$ 23,000,000$ & Biomass to Boiler & 0.0 \\
\hline Neutralization/Conditioning & $\$ 8,400,000$ & CSL & 13.8 \\
\hline Saccharification \& Fermentation & $\$ 20,500,000$ & Cellulase & 32.2 \\
\hline Distillation and Solids Recovery & $\$ 23,400,000$ & Other Raw Materials & 31.1 \\
\hline Wastewater Treatment & $\$ 3,400,000$ & Waste Disposal & 1.9 \\
\hline Storage & $\$ 3,800,000$ & Electricity & -10.4 \\
\hline Boiler/Turbogenerator & $\$ 45,500,000$ & Fixed Costs & 16.0 \\
\hline Utilities & $\$ 5,600,000$ & Capital Depreciation & 20.9 \\
\hline Total Installed Equipment Cost & $\$ 133,500,000$ & Average Income Tax & 15.7 \\
\hline & & Average Return on Investment & 38.3 \\
\hline $\begin{array}{l}\text { Added Costs } \\
\text { (\% of TPI) }\end{array}$ & $\begin{array}{l}\$ 98,200,000 \\
42 \%\end{array}$ & Operating Costs & \\
\hline & & Feedstock & $\$ 46,400,000$ \\
\hline Total Project Investment & $\$ 231,700,000$ & $\begin{array}{l}\text { Biomass to Boiler } \\
\text { CSL }\end{array}$ & $\begin{array}{r}\$ 0 \\
\$ 7,700,000\end{array}$ \\
\hline Installed Equipment Cost/Annual Gallon & $\$ 2.41$ & Cellulase & $\$ 17,900,000$ \\
\hline Total Project Investment/Annual Gallon & $\$ 4.17$ & $\begin{array}{l}\text { Other Raw Matl. Costs } \\
\text { Waste Disposal }\end{array}$ & $\begin{array}{r}\$ 17,200,000 \\
\$ 1,000,000\end{array}$ \\
\hline Loan Rate & $N / A$ & Electricity & $-\$ 5,800,000$ \\
\hline Term (years) & N/A & Fixed Costs & $\$ 8,900,000$ \\
\hline Capital Charge Factor & 0.180 & $\begin{array}{l}\text { Capital Depreciation } \\
\text { Average Income Tax }\end{array}$ & $\begin{array}{r}\$ 11,600,000 \\
\$ 8,700,000\end{array}$ \\
\hline Denatured Fuel Prod. (MMgal / yr) & 58.1 & Average Return on Investment & $\$ 21,300,000$ \\
\hline Denatured Fuel Min. Sales Price & $\$ 2.35$ & & \\
\hline Denaturant Cost (\$/gal denaturant) & $\$ 0.641$ & $\begin{array}{l}\text { Excess Electricity (KWH/gal) } \\
\text { Plant Electricity Use (KWH/gal) }\end{array}$ & $\begin{array}{l}2.61 \\
2.05\end{array}$ \\
\hline Maximum Yields ( $100 \%$ of Theoretical) & & & \\
\hline Ethanol Production (MM Gal/yr) & 87.0 & Plant Steam Use (kg steam/gal) & 18.1 \\
\hline Theoretical Yield (Gal/ton) & 112.7 & Boiler Feed -- LHV (Btu/lb) & 1,594 \\
\hline Current Yield (Actual/Theoretical) & $64 \%$ & Boiler Feed -- Water Fraction & 0.538 \\
\hline
\end{tabular}




\section{REPORT DOCUMENTATION PAGE}

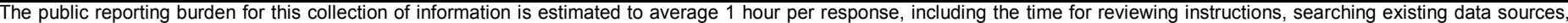

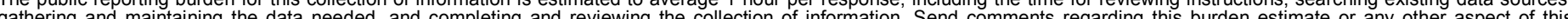

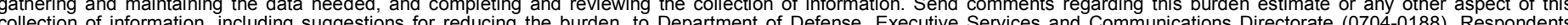

chould be aware that notwithstanding any other provision of law, no

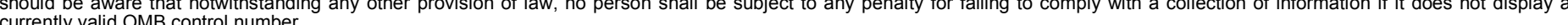

PLEASE DO NOT RETURN YOUR FORM TO THE ABOVE ORGANIZATION.

\begin{tabular}{l|l|l|l} 
1. REPORT DATE $(D D-M M-Y Y Y Y)$ & 2. REPORT TYPE & 3. DATES COVERED (FrOm - TO)
\end{tabular}

May 2008

Technical Report

4. TITLE AND SUBTITLE

Biochemical Production of Ethanol from Corn Stover: 2007 State of

Technology Model

5a. CONTRACT NUMBER

DE-AC36-99-G010337

5b. GRANT NUMBER

5c. PROGRAM ELEMENT NUMBER

6. AUTHOR(S)

A. Aden

5d. PROJECT NUMBER

NREL/TP-510-43205

5e. TASK NUMBER

BB072410

5f. WORK UNIT NUMBER

7. PERFORMING ORGANIZATION NAME(S) AND ADDRESS(ES)

National Renewable Energy Laboratory

1617 Cole Blvd.

8. PERFORMING ORGANIZATION REPORT NUMBER

Golden, CO 80401-3393

NREL/TP-510-43205

9. SPONSORING/MONITORING AGENCY NAME(S) AND ADDRESS(ES)

10. SPONSOR/MONITOR'S ACRONYM(S) NREL

11. SPONSORING/MONITORING AGENCY REPORT NUMBER

12. DISTRIBUTION AVAILABILITY STATEMENT

National Technical Information Service

U.S. Department of Commerce

5285 Port Royal Road

Springfield, VA 22161

13. SUPPLEMENTARY NOTES

14. ABSTRACT (Maximum 200 Words)

An update to the FY 2005 assessment of the state of technical research progress toward biochemical process goals.

This assessment contains research results from 2006 and 2007.

15. SUBJECT TERMS

biochemical; state of technology; SOT; process design

\begin{tabular}{|c|c|c|}
\hline 16. SECURIT & CLASSIFICAT & N OF: \\
\hline $\begin{array}{l}\text { a. REPORT } \\
\text { Unclassified }\end{array}$ & $\begin{array}{l}\text { b. ABSTRACT } \\
\text { Unclassified }\end{array}$ & $\begin{array}{l}\text { c. THIS PAGE } \\
\text { Unclassified }\end{array}$ \\
\hline
\end{tabular}

\begin{tabular}{|c|c|}
\hline $\begin{array}{l}\text { 17. LIMITATION } \\
\text { OF ABSTRACT }\end{array}$ & $\begin{array}{l}\text { 18. NUMBER } \\
\text { OF PAGES }\end{array}$ \\
\hline UL & \\
\hline
\end{tabular}

19a. NAME OF RESPONSIBLE PERSON

19b. TELEPHONE NUMBER (Include area code) 